Fugitive Testimony 
This page intentionally left blank 


\section{Fugitive Testimony}

On the Visual Logic of Slave Narratives

JANET NEARY

Fordham University Press

NEW YORK 2017 
Fordham University Press gratefully acknowledges financial assistance provided for the publication of this book from the Offices of the Provost and the Dean of Arts \& Sciences, Hunter College, City University of New York.

Copyright $@ 2017$ Fordham University Press

All rights reserved. No part of this publication may be reproduced, stored in a retrieval system, or transmitted in any form or by any means-electronic, mechanical, photocopy, recording, or any other-except for brief quotations in printed reviews, without the prior permission of the publisher.

Fordham University Press has no responsibility for the persistence or accuracy of URLs for external or third-party Internet websites referred to in this publication and does not guarantee that any content on such websites is, or will remain, accurate or appropriate.

Fordham University Press also publishes its books in a variety of electronic formats. Some content that appears in print may not be available in electronic books.

Visit us online at www.fordhampress.com.

Library of Congress Cataloging-in-Publication Data available online at http://catalog.loc.gov.

Printed in the United States of America

$191817 \quad 54321$

First edition 
To

Lindon Barrett

and my family 
This page intentionally left blank 